\title{
Sobre o humor em Morte e Vida Severina (1956), de João Cabral de Melo Neto
}

On humor in João Cabral de Melo Neto's Morte

e Vida Severina (1956)

Joelma Santana Siqueira ${ }^{1}$

RESUMO

O poeta João Cabral de Melo Neto, referindo-se à obra Morte e Vida Severina (1956), algumas vezes, comentou que o humor não recebeu a atenção dos críticos. No presente artigo, recuperamos trabalhos que se dedicaram a explorar o humor em sua poesia para, em seguida, analisá-lo na viagem realizada por Severino do Sertão ao Litoral em busca de melhores condições de vida, apresentada como uma ironia.

Palavras-chave: Humor; Morte e vida severina; João Cabral de Melo Neto.

\section{ABSTRACT}

The poet João Cabral de Melo Neto, when talking about Morte e Vida Severina (1956) pointed out, on some occasions, that the humorous aspects of his poem had not received any attention from the critics. In this paper, we retrieve works that concerned themselves with exploring the humor in his poetry with the aim of, afterwards, analyzing its presence in the trip undertook by Severino, from the backlands (Sertão) to the shore, looking for better life conditions, presented as an irony.

Keywords: Humor; Morte e vida Severina; João Cabral de Melo Neto.

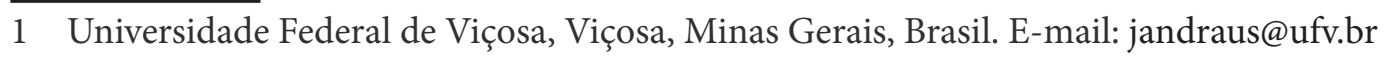


uitos estudos sobre o humor começam por destacar a abrangência
do tema e a impossibilidade de delimitá-lo com precisão. No arti-
go "História cultural do humor: balanço provisório e perspectivas de pesquisa”, Elias Saliba (2017), ao analisar contribuições recentes das pesquisas interdisciplinares dos estudos do humor, destacou que:

\footnotetext{
Enfim, já se produziu uma verdadeira biblioteca, com centenas de volumes, que nos legaram as mais variadas definições sobre o humor e o riso (daquelas que a vida inteira de um estudioso jamais esgotaria) e que nunca lograram sequer a esboçar uma categoria ou ao menos um princípio unificante para as formas cômicas e humorísticas (SALIBA, 2017, p. 11).
}

Preocupada em desenvolver uma abordagem histórica do humor, Verena Alberti (2002), no livro O riso e o risível na história do pensamento, no primeiro capítulo, dedicado ao riso no pensamento do século XX, observou o desaparecimento de certas questões que, no passado, foram centrais nas teorias do riso, "como a condenação (e a tolerância) ética do riso" e o problema da relação entre o riso e a razão. Segundo Alberti, "os pensamentos modernos 
J. S. SiquEIRA

Sobre o humor em Morte e Vida Severina (1956), de João Cabral de Melo Neto sobre o riso parecem compensar o mundo desencantado com um riso infinito e indefinido". Nesse mundo, que não é mais maravilhoso, "é no riso, no nãosério, que se situa agora a possibilidade do impossível”. Propõe que, talvez por isso, o riso moderno não aceite as definições concretas e as classificações de tratados como o Tratté du ris (1579), do médico francês Laurent Joubert. O riso moderno, de acordo com suas palavras,

Alberti destacou, logo no início desse capítulo dedicado ao riso no pensamento do século XX, que um dos estudiosos mais entusiastas do reconhecimento da importância do riso para a filosofia foi o filósofo alemão Joachim Ritter. Reportando-se ao ensaio “Sobre o riso", publicado pelo filósofo em 1940, propôs que "o ponto de partida de Ritter é a relação estreita entre o riso e seu objeto: só se pode definir o riso, diz ele, enquanto ligado ao cômico, que, por sua vez, determinado pelo sentido de existência (Daseinssinn) daquele que ri”.

Partido dessa premissa sobre a dependência daquele que ri, buscamos, agora, ainda que brevemente, discutir alguns trabalhos que se detiveram com mais vagar na discussão sobre o humor na poesia cabralina. $O$ primeiro trabalho dedicado a esse tema, até onde pudemos notar, foi a pesquisa de mestrado realizada por Nancy Maria Mendes, intitulada "Ironia, sátira, paródia e humor na poesia de João Cabral de Melo Neto", defendida em 1980 na Universidade Federal de Minas Gerais. Desse trabalho, resultaram os 
artigos "Morte e vida Severina: um texto parodístico" (1979); "Sete cemitérios sob perspectiva irônica" (1984) e "Humor em poemas de João Cabral" (1984).

No artigo "Morte e vida severina: um texto parodístico", Mendes (1979, p. 46) retoma estudos de Benedito Nunes, Eliane Zagury e João Alexandre Barbosa, e analisa a intertextualidade de caráter parodístico, relacionando-a com três séries de textos: os autos natalinos, os pastoris e os evangelhos, demonstrando que, em relação aos autos natalinos tradicionais, Cabral buscou o modelo esquemático, mas, diferentemente, elaborou um desfecho impregnado de amargura; em relação aos pastoris, usou os mesmos significantes, mas alterou "substancialmente o significado"; por fim, em relação aos textos bíblicos, encontram-se com o "sentido alterado, ou, mais especificamente, são utilizados visando a fins profanos". No artigo "Sete cemitérios sob perspectiva irônica”, Mendes parte de observações de João Alexandre Barbosa, presentes em A imitação da forma (1975), para analisar a ironia em três poemas de Paisagem com figuras (1956) e quatro poemas de Quaderna (1960). Consideramos que é no artigo "Humor em poemas de João Cabral" que a pesquisadora explora mais detidamente o tema, ao identificar o humor como constituído pelo trágico e pelo cômico, oscilando

\begin{abstract}
entre essas duas fronteiras, que se deixa de algum modo contaminar por um e por outro elemento, sem, contudo, comprometer-se com nenhum deles. Ora se mostra benevolente, ora atinge a extrema amargura, mas revela-se sempre paradoxal, focaliza situações ou figuras que seriam cômicas, se não se apresentassem com uma grandiosidade que as resgata do ridículo; apresenta figuras sofredoras e situações dolorosas sob um aspecto quase cômico, o que as impede de serem alvo de uma compaixão lacrimosa. Ele revela uma espécie de aceitação dos fatos que não se confunde com a resignação (MENDES, 1984, p. 205).
\end{abstract}

Segundo Mendes, o humor, considerado no sentido acima, "só se registra numa etapa mais avançada da obra de João Cabral e em número relativamente reduzido de poemas", identificando-o "prenunciado em alguns poemas referentes à mulher em Quaderna" e manifestado "de forma evidente em Serial e A educação pela pedra". Relembrando-se de que, anteriormente, Benedito Nunes (1974), no capítulo "A máquina do poema”, abordou o humor em A educação pela pedra (1966), destaca que, "não chega, entretanto, a distingui-lo da ironia e da sátira", como pretende fazer em seu texto.

Como é possível perceber pelas referências a João Alexandre Barbosa, Eliane Zagury e Benedito Nunes nas pesquisas de Nancy Mendes, outros críticos não deixaram de notar a presença do humor na obra de João Cabral, embora esse aspecto não tenha sido o foco principal de suas análises. 
J. S. SiquEIRA

Sobre o humor em Morte e Vida Severina (1956), de João Cabral de Melo Neto
Nesse sentido, relembro o trabalho de Alexandre Shiguehara (2010, p. 86), intitulado Ao longo do rio - João Cabral e três poemas do Capibaribe, fruto de sua tese de doutorado e dedicado à análise da poesia social nos três poemas sobre o Capibaribe publicados nos anos 1950. Analisando mais detidamente o que Benedito Nunes identificou em Morte e vida severina como ritmo da tragédia (do início até o anúncio do nascimento do filho de seu José Mestre Carpina) e ritmo da comédia (a partir do anúncio do nascimento da criança), no subcapítulo "Humor e morte", Shiguehara considera que há humor no emprego que o poeta faz de palavras do campo semântico da religiosidade e tons relacionados ao rito religioso; humor negro na cena dos Irmãos das almas; e humor mais sarcástico no diálogo entre os coveiros.

Outro trabalho a ser destacado é o artigo de Zênia de Faria (2011, p. 215), intitulado "Aspectos do grotesco na poesia de João Cabral de Melo Neto", em que relaciona o grotesco presente em poemas de João Cabral ao 'realismo grotesco', ou seja, ao 'sistema de imagens da cultura cômica popular', proposto por Bakhtin; e a outras marcas do grotesco indicadas por Kayser, a saber: a noção de 'estranhamento', de 'mundo às avessas', explicando que "se faz presente, não só pela equivalência constante entre homem, animal, vegetal e mineral, mas principalmente por uma certa inversão da hierarquia entre esses elementos, na qual, muitas vezes, o homem ocupa uma posição inferior à dos demais elementos da natureza que citamos". Observa a presença do grotesco na poesia de Cabral associada ao tema da morte, destacando que "essa temática, que pressuporia um tratamento sério, mais de acordo com as circunstâncias que a envolvem, é, com frequência, abordada pelo autor de modo irreverente, sarcástico, irônico ou humorístico". Reconhecendo a presença dessa temática em vários poemas de Cabral, como, por exemplo, em passagens de Morte e vida severina, selecionou para análise os poemas "Duas das festas da morte", "Retrato de poeta" e algumas passagens dos seguimentos "Descoberta da Usina" e "Encontro com a Usina", da obra $O$ rio ou a relação da viagem que faz o Capibaribe de sua nascente à cidade do Recife.

O último trabalho que destacamos por ter na análise do humor o seu objetivo central é o de Alessandra Carvalho (2015, p. 124), intitulado "O humor de inspiração ibérica na poesia de João Cabral de Melo Neto". De acordo com Carvalho, há na obra do poeta "um conjunto de poemas que se centram no infundio, ou imaginação fantasiosa, traço característico que o poeta destaca da personalidade do sevilhano". Mas esclarece que o interesse não é pelo "maneirismo que poderia estar por detrás do jeito infundioso de expressar-se”, pois 
nal. Em lugar da rigidez protocolar, cria-se empatia pela própria piada que pede a intervenção de certo sentido crítico nada severo, provocando um riso liberador e, por isso mesmo, sublime (CARVALHO, 2015, p. 124).

Alessandra Carvalho analisa principalmente poemas da obra Andando Sevilha (1990), mas também de A educação pela pedra (1966) e Agreste (1985), concordando com Cabral sobre a existência de uma lacuna em sua fortuna crítica relacionada à análise do humor, também observada por Zênia de Faria. A esse respeito, vale destacar que, pelo menos em três ocasiões, João Cabral se manifestou sobre a ausência de análises do humor em sua poesia, mencionando as obras Morte e vida severina (1956) e Dois parlamentos (1960). Antes de comentá-las, lembramos de que, em artigo originalmente publicado em 1964, com o título "O humor na poesia moderna do Brasil", o crítico e poeta Cassiano Nunes considerou que houve o amortecimento do emprego do humor nos poetas de 45 e, aproximando o primeiro livro de Cabral da poesia dos poetas modernistas, com destaque para Murilo Mendes, escreveu: "o domínio da metáfora é perfeito em João Cabral de Melo Neto, a sua maneira de operar poeticamente é limpa, mas a sua sátira e o seu sarcasmo estão quase que completamente divorciados do cômico" (NUNES apud MAMEDE, 1987, p. 256). Em 1977, em entrevista para o Jornal Amostragem, João Cabral destacou algo contrário a essa observação quando disse que, depois de Morte $e$ Vida Severina, começou a ver que sua poesia é dramática, "não no sentido de ter sido escrita para o teatro e nem no sentido de ser drama, mas porque existe nela um elemento de ironia e sarcasmo, sem haver um interlocutor vivo" (MELO NETO apud ATHAYDE, 1998, p. 108). O poeta falou do humor que está presente em sua poesia em entrevista concedida a Augusto Massi, em 1987. Após ser questionado se "algum aspecto de sua obra ficou relegado ou não foi apontado pela crítica? O privilégio dado à questão da linguagem ofusca outros procedimentos de sua poética?", respondeu:

Há um aspecto da minha poesia que, parece, foi o menos estudado. Eu talvez imagine que tenha importância e, vai ver, ele não tenha nenhuma. Pode ser um erro de perspectiva da minha parte. Penso no humor. Não me lembro de ter nenhum ensaio ou artigo interessante sobre o problema do humor na minha poesia. O humor a que me refiro está em Morte e vida severina, está em Dois parlamentos, é uma espécie de vaia na miséria. Em Dois parlamentos ninguém tem pena do cassaco de engenho, pelo contrário, ele é até meio ridicularizado. Esse é um tipo de humor às avessas, que é o humor de Cervantes (MELO NETO apud MASSI, 1987). 
J. S. SiquEIRA

Sobre o humor em Morte e Vida Severina (1956), de João Cabral de Melo Neto
Na sequência, falou um pouco sobre o que é o humor de Cervantes, seu procedimento semelhante ao do escritor espanhol e a importância desse humor:

\begin{abstract}
Cervantes não tem ternura por Dom Quixote, no primeiro volume é uma vaia permanente. No segundo, ele já enxerga a grandeza do personagem e trata Dom Quixote com mais carinho. Mas no primeiro só espinafra.
\end{abstract}

Tenho um procedimento semelhante, ao invés de me solidarizar com o cassaco de engenho e espinafrar o usineiro, faço o usineiro espinafrar o cassado de engenho. Tratando o humor às avessas, o texto não fica piegas, não fica retórico, não vira comício. Esse humor não foi analisado pela crítica (Idem).

Tempos depois, novamente em entrevista concedida a Augusto Massi, em 1991, para o jornal Folha de S. Paulo, falou do humor na segunda parte da matéria que trazia como manchete "Nunca analisaram meu humor, diz João Cabral". No corpo da entrevista, esse assunto aparece após a última pergunta de Massi: "Há algum aspecto de sua obra que não foi observado pela crítica?”. Em resposta, Cabral comentou: "Escreveram tanto sobre mim que eu não vejo claro esta coisa. Eu não vivo lendo a minha obra, mas eu tenho a impressão que, inclusive em 'Dois parlamentos' e 'Morte e vida severina', o humor é um dos aspectos dos meus livros que não chamou a atenção de ninguém” (MELO NETO, 1991, p. 6). Tempos depois, em entrevista publicada nos Cadernos de literatura (1996), após outra pergunta sobre a recepção crítica de sua obra, "Voltando ainda à ideia de limites, quais seriam agora os da crítica em relação à exegese de sua obra?", o poeta falou em humor negro, citou Dois Parlamentos e exemplificou com uma passagem de Morte e vida severina:

A crítica nunca se preocupou com o humor negro de minha poesia. Leia Dois parlamentos, por exemplo. É puro humor negro. Em Morte e vida severina, também existe humor negro. Você lembra daquele trecho: 'Mais sorte tem o defunto/ irmão das almas/ pois não fará na volta/ a caminhada'? Pois bem. A origem disso é uma história que me contaram na Espanha. Dizem que, na época de Franco, ele mandava fuzilar seus inimigos num lugar chamado Sória, que é o mais frio do país. Conta-se que, um dia, um condenado virou-se para os soldados que iriam executá-lo e disse: 'Puxa, como faz frio nesse lugar'. Ao que um dos soldados respondeu: 'Sorte tem você, que não precisa fazer o caminho de volta'. Foi assim que essa frase foi parar no meio de Morte e vida severina. Há mais humor negro do que isso? (MELO NETO, 1996, p. 27).
Revista Letras,

Curitiba, UFPR, n. 102 , pp. $69-93$, jul./dez. 2020 ISSN 2236-0999 (versão eletrônica) 
Quando Cabral concedeu essas entrevistas, Nancy Mendes já havia finalizado sua dissertação e publicado os três artigos de que falamos neste artigo, mas, nas décadas de 1980 e 1990, o acesso à produção do meio acadêmico não era tão fácil quanto no mundo globalizado de hoje em dia.

Voltando à última entrevista citada, a anedota contada por Cabral não seria necessária para identificarmos o humor negro na referida passagem de Morte e Vida Severina, especialmente se lermos a obra, desde seu início, atentos às marcas de humor. Nesse sentido, Nancy Mendes, no artigo "Morte e Vida Severina: um texto parodístico", observando o caráter de inversão da obra desde seu título, destacou:

\begin{abstract}
Mais que a função adjetiva desempenhada pelo substantivo próprio Severino, causa estranheza o fato de a palavra 'morte' preceder 'vida' no título. Prova disso é o frequente lapso de muitos, que, mesmo familiarizados com o texto, se referem à obra como 'Vida e morte severina'. Por outro lado, o adjetivo usado, quer em relação a 'morte', quer em relação a 'vida', longe de conotar qualquer ideia relativa a Cristianismo, a repele. (MENDES, 1979, p. 39).
\end{abstract}

O lapso de inverter as palavras morte e vida ocorre em muitas situações. Por meio de pesquisa no site da Hemeroteca Digital ${ }^{2}$ verificamos que a expressão "Vida e morte Severina" para se referir ao auto de Cabral nos anos 1950 ocorreu em muitos jornais. Para citarmos alguns exemplos: Correio da Manhã (RJ), seis ocorrências; Diário da noite (SP), cinco; Diário de Pernambuco (PE), quatro.

Morte e vida severina é a obra de João Cabral mais conhecida do grande público, seja pelo aspecto mais comunicativo, questionável, mas reconhecido pelo poeta ao destacar que isso se deve ao fato de ter escrito o texto para o teatro; seja pela mise-en-scène do Teatro da Pontifícia Universidade Católica de São Paulo, o TUCA, na década de 1960, com música de Chico Buarque de Holanda; seja pelas inúmeras adaptações para diversos suportes, televisão, quadrinhos, animação etc. Não tem sido a mais conhecida, porém, pelo humor e ironia que apresenta. Mesmo no artigo em que analisa a inversão parodística presente no auto cabralino, Nancy Mendes (1979, p. 49) não discute o humor, aponta a ironia na fala das pessoas que trazem presentes para o recém-nascido e na fala das ciganas (como veremos mais adiante), e, concordando com o conceito de paródia como sendo "a um só tempo, homenagem respeitosa e um gesto de vaia ('pied de nez') à tradição", proposto por Hutcheon, acertadamente, escreve:

2 Consultar http://bndigital.bn.gov.br/hemeroteca-digital/ 
J. S. SIQUEIRA

Sobre o humor em Morte e Vida Severina (1956), de João Cabral de Melo Neto pode-se talvez concluir que, das três séries de textos parodiados, todos com o mesmo significado de exaltação do nascimento, a homenagem do Autor dirige-se às duas primeiras séries, enquanto "un ironique pied de nez" se reserva à terceira delas, isto é, aos textos evangélicos que as inspiram. Utilizá-los para evidenciar uma situação de miséria sem saída é, praticamente, fazê-los voltar contra si mesmos, é colocar diante do leitor a lembrança da crença cristã no Salvador, contestando-a (MENDES, 1979, p. 49).

Concordamos com a leitura de Mendes e destacamos que nossa leitura de Morte e vida severina buscará demostrar que o humor não se restringe a uma passagem ou outra do auto. Observamos a viagem de Severino como uma grande ironia interligada à ironia do nascimento de uma vida severina na periferia da cidade grande. A análise de conceitos como o de paródia, grotesco e infundio demostram procedimentos que possibilitam o riso trágico, aquele que direciona a atenção do objeto de que se ri para a atitude de quem ri.

O fio condutor que une as cenas do auto é a viagem que o retirante Severino faz do interior do sertão até a capital de Pernambuco, Recife, seguindo o curso do rio Capibaribe, em busca de trabalho e, portanto, de melhores condições de vida. Ele passa por cidades, simples arruados, vilas pequenas e até áreas descampadas, deparando-se com a seca, violência por disputas de terra, a decadência dos engenhos, a falta de trabalho para o homem do campo e, por fim, a falta de expectativas para esse mesmo homem na cidade grande. Nesse caminho, a morte em consequência desses males, é frequente. O texto termina com a notícia do nascimento de uma criança. A última fala é a resposta do pai, Seu José Mestre Carpina, à seguinte pergunta de Severino:

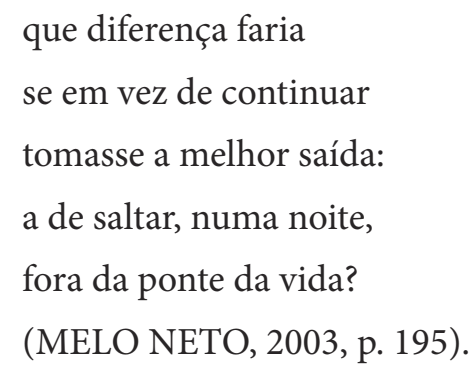

Essa pergunta é feita depois de Severino, finalmente, ter chegado ao Recife. Seu José Mestre Carpina é morador de um dos mocambos que existem entre o cais e a água do rio. No Recife, Severino deparou-se com uma realidade que não corresponde ao que ele esperava. Fica sabendo das péssimas condições de vida do homem pobre na cidade, vivendo em mocambos, moradias insalubres que atestam a desigualdade social e a falta de planejamento urbano na cidade destino do retirante. Na contramão da euforia desenvolvimentista dos anos 1950, o auto nos apresentava a precariedade da vida, seja no sertão arcaico, seja na periferia degradada da cidade moderna. Fazia isso com uma
Revista Letras,

Curitiba, UFPR,

n. 102 , pp. 69-93,

jul./dez. 2020

ISSN 2236-0999

(versão eletrônica) 
visão irônica e sarcástica. A primeira ironia que queremos destacar é a que Muecke (1995, p. 39) chamou de "Ironia Observável”, incluindo “sejam ironias de eventos, de personagens (auto ignorância, auto traição), de situação, sejam de ideias (por exemplo, as contradições internas inobservadas de um sistema filosófico como o marxismo) - podem ser locais ou universais". Observando que o conceito abarca o desenvolvimento do conceito de WeltIronie, Ironia Cósmica ou Ironia Geral, acrescenta: “a ironia do universo que tem, como vítima o homem ou o indivíduo". Entre outros exemplos de Ironia Observável, cita: "o modo como o evento inverte nossas esperanças ou medos; Clitemnestra exultante em sua segurança quando, como sabe a plateia, sua sentença já está selada” (p. 44).

Severino não é uma personagem exultante. Ele parte do sertão com a esperança de uma vida melhor no Recife, vindo a saber, por meio da conversa entre dois coveiros, que, na cidade, retirantes como ele encontram morte e miséria. Os coveiros reclamam de enterrar essa gente pobre que chega ao litoral:

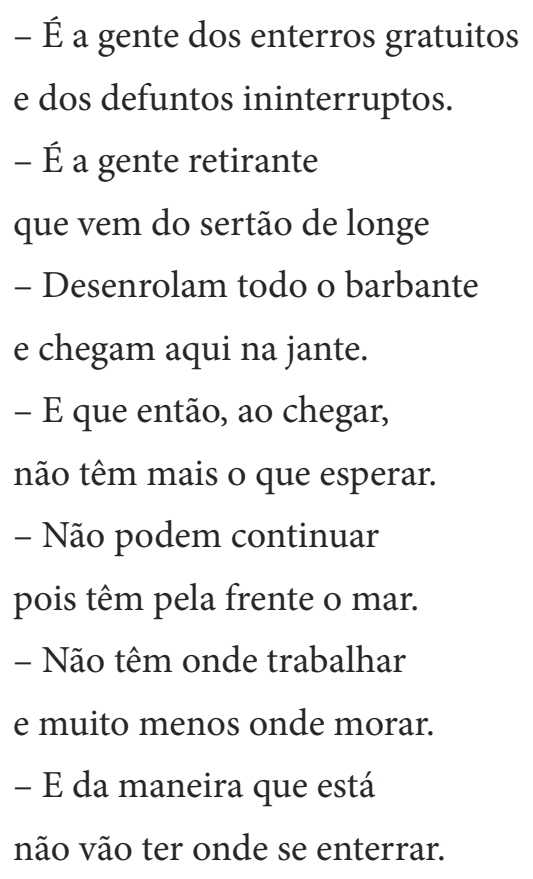

(MELO NETO, 2003, p. 190-1).

Severino se depara com uma condição de morte e vida pior do que a do sertão, porque, segundo os coveiros, é grande o número de retirantes que morrem na cidade, "E da maneira que está/ não vai ter onde se enterrar". Ironicamente, Severino é recepcionado por coveiros que ignoram sua presença e, no diálogo que mantêm entre si, revelam para o retirante seu engano:

\footnotetext{
- Não é viagem o que fazem, vindo por essas caatingas, vargens;

aí está o erro:

vêm é seguindo seu próprio enterro
} 
J. S. SiQUEIRA

Sobre o humor em Morte e Vida Severina (1956), de João Cabral de Melo Neto

O texto é composto de 18 passagens introduzidas por rubricas e que podem ser dividias em duas partes: 1 a 9, a viagem até o Recife; 10 a 18, no Recife. As rubricas introduzem os lugares, as personagens e as ações que Severino retirante encontra pelo caminho. Morte e vida, desprovidas dos adornos místicos, assumem aspecto de coisa puramente material, nesse sentido, concreta. As referências religiosas são dessacralizadas por associação à vida mundana, como ocorre em relação aos nomes de Santos e Profetas: Severino é filho de Maria do finado Zacarias, mas, como ele, há muito outros Severinos "com mães chamadas Maria". E como houve na freguesia um coronel de nome Zacarias, mais antigo senhor dessa sesmaria, ficou sendo "Severino da Maria do Zacarias, lá da serra da Costela, limites da Paraíba". Severino como tantos dessa região de Zacarias donos de terra, latifundiários.

A posse da terra é um tema recorrente ao longo da viagem, mas aparece de soslaio, como nessa passagem que informa sobre a origem do nome do pai de Severino, Zacarias, por causa de um homônimo dono de sesmaria, sistema de distribuição de terra que está na base do latifúndio no Brasil, sobretudo no Nordeste. Severino é o típico retirante nordestino, e a impossibilidade de individualizá-lo (seja por meio de seu nome, sua história, sua fisionomia, sua morte e sua sina de trabalhador na terra improdutiva, na usina ou nas fábricas da cidade grande) aponta para a precariedade da constituição individual do homem que vive nas mesmas condições de pobreza, mas também contribui para o humor, no sentido de que, como destacou Henri Bergson (1993, p. 71), "a semelhança a um tipo tem qualquer coisa de cômico". O assunto grave é permeado de imagens, situações, expressões risíveis, associadas ao emprego da Ironia Observável e da Ironia Instrumental. Segundo Muecke (1995, p. 38), a primeira diz respeito a "coisas vistas ou apresentadas como irônicas", e a segunda, a "alguém sendo irônico", no entanto, esclarece: "o que chamei de Ironias Observáveis existe apenas potencialmente nos fenômenos observados e torna-se efetivo somente através da apresentação; quanto mais hábil for a apresentação, mais clara é a situação irônica 'observada"' (p. 85).

A viagem de Severino em busca de uma vida melhor é uma Ironia Observável sobretudo pelo público do auto que ao menos desconfia de antemão o que espera pelo retirante na grande cidade. Severino ser informado de seu malogro por coveiros que se dizem cansados de enterrar retirantes, com frases cômicas, como "Fique-se por aí um momento/ e não tardarão a aparecer/ os defuntos que ainda hoje/ vão chegar (ou partir, não sei)", tem um humor que nos distancia da piedade por Severino, para nos fazer refletir sobre sua condição a partir do entendimento dessas camadas irônicas do texto. Perceber como a viagem de Severino se apresenta, permite-nos observar que o riso irônico tem a função de fazer arrefecer o sentimentalismo em prol da 
reflexão. O riso de que estamos falando aproxima-se da noção de riso trágico discutida por Verena Alberti (2002, p.22) a partir de textos de Georges Bataille ao destacar, citando-o, que o riso trágico "tem menos a ver com o objeto do riso (o trágico de que se ri) do que com a atitude daquele que ri”. Quando você ri, "você se percebe cúmplice de uma destruição daquilo que você é, você se confunde com esse vento de vida destruidora que conduz tudo sem compaixão até seu fim”". Nesse sentido, o que se tem ao rir é “'o acordo (...) de nossa alegria com um movimento que nos destrói', em última instância, com a própria morte. Nesse caso, não é por rir da morte, e sim, por se confundir com a morte, que esse riso se torna inseparável de um sentimento trágico".

Já na primeira cena do auto, no monólogo em que Severino se apresenta, a descrição de si é caricatural ao selecionar as seguintes partes do corpo: cabeça grande, ventre crescido e pernas finas:

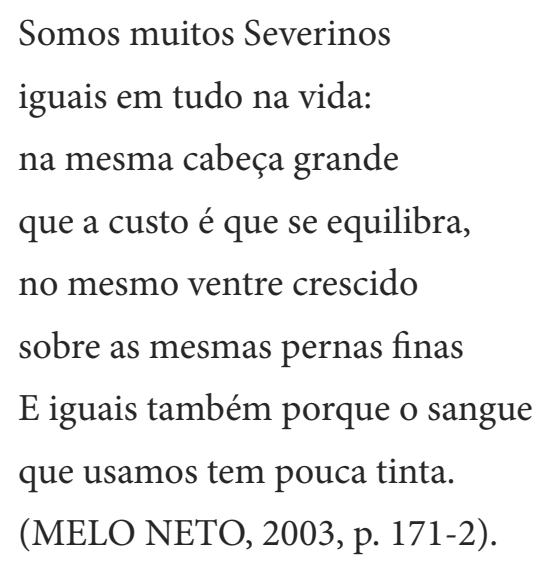

$\mathrm{Na}$ segunda cena, dois homens carregam um defunto embrulhado em uma rede "aos gritos": "Ó irmãos das almas! Irmãos das almas! Não fui eu que matei não!'. Um desses homens informa que o defunto se chamava "Severino Lavrador, mas já não lavra". Quando informa que o defunto foi morto por uma bala, logo acrescenta: "mais garantido é de bala, mais longe vara"; "sempre há uma bala voando desocupada"; "mais sorte tem o defunto, irmãos das almas, pois já não fará na volta a caminhada”. As passagens que destacamos são cômicas pelo modo e contexto em que são enunciadas, "aos gritos”, pelos que carregam o corpo de um morto. O motivo da morte é a disputa de terra em território sem lei. Como vimos mais acima, João Cabral explicou que o humor negro dessa última passagem tem origem em uma história que lhe contaram na Espanha, mas a passagem está carregada de outras frases que também apresentam humor associado à morte violenta.

Nancy Maria Mendes, no artigo "Humor em poemas de João Cabral", que não se detém em Morte e vida severina, a respeito do poema "O urubu mobilizado", escreveu que

o leitor vai sendo simultaneamente solicitado por dois pólos: o do trágico e o do cômico, sem que lhe seja possível ultrapassar as 
J. S. SIQUEIRA

Sobre o humor em Morte e Vida Severina (1956), de João Cabral de Melo Neto fronteiras de um ou de outro. A evocação da verdadeira carnificina provocada pela seca não é amenizada, mas deixa de atingir dimensões trágicas. Parece ser indubitável que aí se realiza o humor negro (MENDES, 1984, p. 212).

Podemos pensar sobre esses dois polos instransponíveis também em relação à obra Morte e vida severina, que, no entanto, tem sido lida muito mais pelo polo do trágico. Mendes, ao analisar a inversão paródica no auto cabralino, não observou a presença do humor na obra, destacando o tom irônico no jogo realizado com o nome das frutas e outras iguarias ofertadas ao recém-nascido, presentes nos versos abaixo:

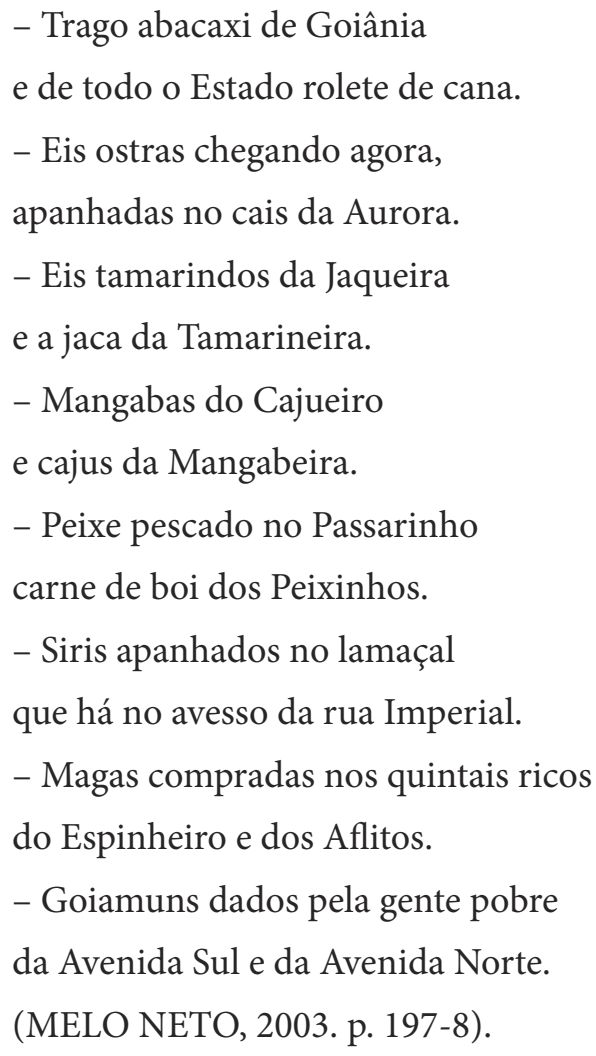

Interessante notar, também, que Jaqueira, Tamarineiro, Cajueiro, Mangabeira, Passarinho, Espinheiro e Aflitos são nomes de bairros do Recife. Cabral traz referências da cidade que promovem nosenses como "Mangabas do Cajueiro".

A seca, presente a partir da viagem do retirante em busca de melhores condições de vida no litoral, é retomada na cena em que ele teme extraviar-se porque seu guia, o rio Capibaribe, secou com o verão. O percurso que faz é comparado a um rosário em que as contas são as paragens com vilas, cidades, arruados e espaços vazios de tudo. Ao ouvir o que lhe parece cantoria, novena de santo, festa ou dança, Severino depara-se com o canto de excelências a um defunto e, na parte de fora da casa, há um homem parodiando as palavras dos cantadores. Dois aspectos se destacam: a religiosidade popular, as excelências, em substituição à extrema unção, especialmente em lugares em que os
Revista Letras,

Curitiba, UFPR, n. 102, pp. 69-93, jul./dez. 2020 ISSN 2236-0999 (versão eletrônica) 
representantes oficiais da Igreja não chegam; e a paródia do canto sagrado, proferida do lado de fora da casa:

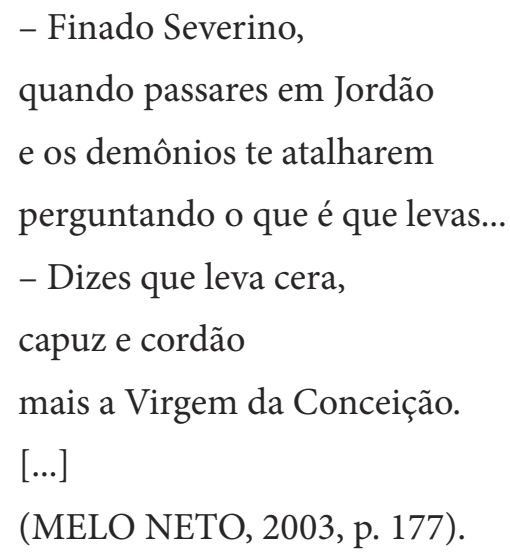

No rio Jordão, João Batista batizou Jesus Cristo. Parodiando os cantadores de excelências, o homem profana a cerimônia e um espaço sagrado do cristianismo, colocando em Jordão os demônios como inquiridores do finado. A paródia também esvazia o significado transcendente das excelências, substituindo-o, ironicamente, pelo sentido material da morte como plantação e colheita para a terra:

- Duas excelências...

- ... dizendo é a hora da plantação.

- Ajunta os carregadores...

- ...que a terra vai colher a mão.

Cansado da viagem, o retirante decide parar e procurar por trabalho. Dirige-se a uma mulher que se encontra debruçada em uma janela. Ela informa que, ali naquele lugar, de nada serve o ofício de lavrador, vive de cantar excelências, velar defuntos. Observa-se a primeira referência à substituição dos engenhos pelas usinas, tema recorrente no romance Usina, de José Lins do Rego, publicado pela Editora José Olympio em 1936 e reeditado em 1940, 1949 e 1956, mesmo ano de publicação do volume Duas águas, também pela editora José Olympio, coletânea que reúne obras anteriormente publicadas e os inéditos Morte e vida severina, Paisagens com figuras e Uma faca só lâmina. $\mathrm{Na}$ passagem abaixo, a narrativa de José Lins expõe com realismo sério a precariedade da vida do trabalhador do campo após a chegada da usina:

Com a usina, eles haviam ficado mais pobres, mas miseráveis. $\mathrm{O}$ senhor de engenho ainda consentia que ficassem com dois dias para eles. Eram donos de dois dias da semana para fazer o que bem lhes viesse às ventas. A usina comera-lhes estas regalias. A semana inteira e nos dias de moagem, de domingo a domingo, de 
J. S. SiQueIRA

Sobre o humor em Morte e Vida Severina (1956), de João Cabral de Melo Neto dia e de noite (REGO, 1956, p. 238).

No auto, a mulher da janela informa a Severino que, com a vinda das usinas, há poucos engenhos por lá. Ironicamente, ela vive da morte:

\author{
Só os roçados na morte \\ Compensam aqui cultivar, \\ e cultivá-los é fácil: \\ simples questão de plantar \\ não se precisa de limpa, \\ de adubar nem de regar; \\ as estiagens e as pragas \\ fazem-nos mais prosperar; \\ e dão lucro imediato; \\ nem é preciso esperar \\ pela colheita: recebe-se \\ na hora mesma de semear.
}

(MELO NETO, 2003, p. 182).

A apresentação da morte como um negócio lucrativo, que não exige muito trabalho e possibilita a condição material de quem vive, sintetiza, mais uma vez, o par "morte e vida" despojado de idealizações e sentimentalismos. A ironia observável se apresenta no elogio da personagem ao fato de ser a morte de uns o sustento fácil de outros.

Severino chegou à Zona da Mata e não encontrou ninguém, só plantação de cana, usina e um banguê velho em ruína. Pergunta-se por onde andam as gentes do lugar e supõe que estejam "feriando" nessa terra.

\author{
tão fácil, tão doce, tão rica \\ não é preciso trabalhar \\ todas as horas do dia \\ os dias todos do mês \\ os meses todos da vida
}

(MELO NETO, 2003, p. 183).

Muecke (1995, p. 55) observou que na Ironia Observável, "segundo parece, é que temos a alazonia e o alazon, definindo-se a alozonia como inconsistência confiante encontrada no ou imputada ao alazon, a vítima da ironia". Na Ironia instrumental, "em vez de um alazon realmente inconsciente de que sua linguagem ou comportamento num determinado contexto está incongruentemente em desacordo com a situação tal como a vê o observador, temos um ironista afirmando inconsciência" (p. 57). Severino e outras personagens do auto estão mais próximas do alazon do que do ironista. A
Revista Letras,

Curitiba, UFPR, n. 102, pp. 69-93, jul./dez. 2020 ISSN 2236-0999 (versão eletrônica) 
resposta à pergunta de Severino virá com o enterro de um trabalhador do eito. Severino escuta o que dizem do defunto os amigos que o levam em uma rede:

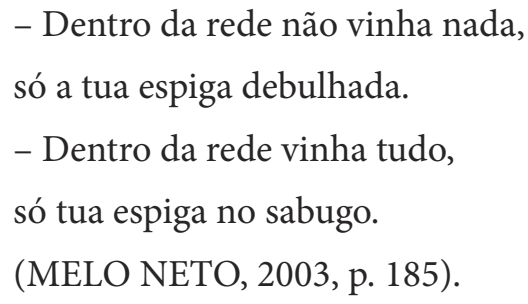

O corpo do defunto é, paradoxalmente, um nada que é tudo, mas o modo de figurá-lo, como uma espiga sem grãos, atende ao propósito de quebrar com a comoção porque essa transmutação do corpo morto em sabugo de milho é risível. A cova em que o corpo será enterrado associa-se ao tema do latifúndio no Nordeste. Ele está agora na "terra que querias ver dividida". Esse corpo despersonalizado, que, em vida, não viu a terra ser dividia, na morte, está em "uma cova grande para teu defunto parco" e "mais que no mundo te sentirás largo". A ironia, tanto em relação à imagem do corpo defunto, um sabugo de milho, quanto em relação ao que dizem da terra que esse corpo irá ocupar, aproxima-se de uma definição de ironia dada por Muecke (1995, p. 48) como "a forma da escritura destinada a deixar aberta a questão do que pode significar o significado literal: há um perpétuo diferimento da significância”. Ironia, nesse caso, "é dizer alguma coisa de uma forma que ative não uma, mas uma série infindável de interpretações subversivas". Outras passagens dessas falas também são igualmente irônicas: "É uma cova grande/ para tua carne pouca/ mas a terra dada/ não se abre a boca”. A terra não foi dada, o defunto não pode falar, a terra extensa é desejável em vida etc.

Ao chegar no Recife, o retirante apreende que não há grande diferença entre o Agreste e a Caatinga e entre a Caatinga e a Mata, pois considera que "quer nesta terra gorda, quer na serra, de caliça, a vida arde sempre com a mesma chama mortiça". Ele escuta a conversa de dois coveiros sobre as dificuldades da profissão, ambos ressaltando a diferença entre trabalhar em cemitério de rico e cemitério de pobre: bairro dos usineiros, políticos, banqueiros, industriais e alguns profissionais liberais; bairro dos funcionários, jornalistas, escritores, artistas, lojistas, bancários, altas patentes dos comerciários e "profissões liberais que não se liberam jamais"; subúrbio dos industriários, ferroviários, rodoviários, comerciários; subúrbio dos operários e dos pobres vários; finalmente, subúrbio dos indigentes, "gente sem instituto", "gente dos enterros gratuitos", "gente retirante que vem do Sertão de longe". Na cidade, a desigualdade social tem muitas gradações e, na base da pirâmide social, está o retirante, o indigente, que "não tem onde trabalhar e muito menos onde morar". Os coveiros trabalham nos cemitérios de Santo Amaro e de Casa Amarela, e comparam a demanda de serviços, enterros, em determinados 
J. S. SIQUEIRA

Sobre o humor em Morte e Vida Severina (1956), de João Cabral de Melo Neto locais da cidade: "As avenidas do centro,/ onde se enterram os ricos,/ são como o porto do mar;/ não é muito ali o serviço:/ no máximo um transatlântico"; no setor de Santo Amaro, "é como a estação de trens: diversas vezes por dia/ chega o comboio de alguém"; e no de Casa Amarela, "Pode ser uma estação/ mas não estação de trem:/ será parada de ônibus,/ com fila de mais de cem". É risível a comparação se nos apercebermos que, nas avenidas do centro, o caixão é comparado a "transatlântico"; no Santo Amaro, a comboio; e no Casa Amarela, a ônibus, em paradas "com filas de mais de cem", imagem muito familiar para os mais pobres das grandes cidades brasileiras. O luxo com o qual os mais ricos são enterrados é posto em contrapartida à mortandade dos mais pobres. Durante o diálogo, um dos coveiros sugere que seria mais rápido e mais barato para "essa gente do sertão/ que desce para o litoral sem razão" que "os sacudissem de qualquer ponte dentro do rio e da morte".

Ao longo do percurso de Severino, as falas das personagens desvelam algo inerente ao processo de modernização chamado de "refugo humano", população excedente, nas palavras de Zygmunt Bauman (2005, p. 24) quando ressaltou que "desde o início dos tempos modernos, cada geração sucessiva tem tido seus naufrágios no vácuo social: as 'baixas colaterais' do progresso, essa "marca registrada da era moderna" que foi apregoada "sob o slogan de mais felicidade para um número maior de pessoas", quando, talvez, "tivesse a ver, em última instância, com a necessidade de menos (e cada vez menos) pessoas para manter o movimento, acelerar e atingir o topo, o que antes exigiria uma massa bem maior para negociar, invadir e conquistar". Severino é o alazon que acreditou que o progresso presente na cidade grande lhe traria benefício.

O diálogo dos coveiros, em verso livre, é mais direto e áspero. Como observou Shiguehara (2010, p. 86) "talvez possa ligar-se também a uma dispersão do sentimento de luto, cuja tonalidade fúnebre pesava sobre as cenas anteriores". Além disso, como observou Renan Nuernberger (2020, p. 189), "ao contrário do que se supõe normalmente, a peça apresenta uma estrutura bastante complexa, com uma grande variedade estilística dentro de seu próprio gênero". O uso do verso livre reforça "a conhecida associação entre a liberdade métrica e o dinamismo da cidade". Observamos que, na cidade, o trabalho com a morte, despojado do canto, é mecânico, daí um olhar mais impiedoso, parecendo concretizar, finalmente, a Ironia Observável, já que, na primeira parte do auto, como explicou João Cabral em entrevista publicada no jornal O Popular, de Goiânia, em 1981, tem-se "um monólogo com pequenas interferências, que são como choques para a esperança de todo retirante" (MELO NETO apud ATHAYDE, 1998, p. 109).

Depois de ouvir o diálogo dos coveiros, Severino aproxima-se de um dos cais do Capibaribe, pensa na morte sugerida, porém aproxima-se dele o morador de um dos mocambos, e tem lugar o diálogo com Seu José Mestre Carpina. A última pergunta do retirante, sobre que diferença faria se em vez 
de continuar saltasse fora da ponte da vida, é entrecortada pela notícia do nascimento do filho de Mestre Carpina, seguida da cena sobre a chegada dos vizinhos, amigos e duas ciganas. Marly de Oliveira (1994, p. 18), concordando com Cabral de que o auto "é uma homenagem às várias literaturas ibéricas", destacou que "o nascimento de Cristo se tornou um fato realista". Seu futuro, no entanto, não é nada promissor nas leituras de sua "sorte futura" realizadas pelas duas ciganas. A primeira prevê que chegará a pescador de maré, e a segunda, ironicamente, acrescenta que não ficará só nisso, será trabalhador de fábrica, sujo de "graxa de máquina":

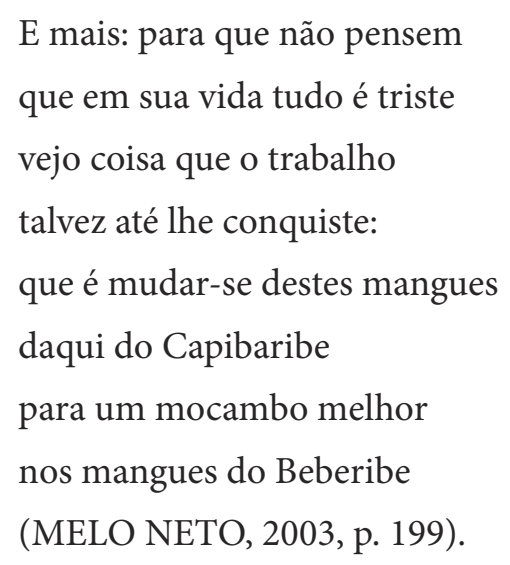

De acordo com a segunda cigana, no futuro, o trabalho como operário poderá possibilitar ao menino mudar para o mangue do rio Beberibe, que, ironicamente, rima com Capibaribe. A fala é irônica porque o menino terá mais do mesmo, anunciado como se fosse uma ascensão social importante. Shiguehara (2010, p. 98) considerou que, com as falas das ciganas "o auto responde criticamente aos discursos de modernização que, durante os anos 1950, identificavam mecanicamente o crescimento industrial e o desenvolvimento do país". Mas consideramos que, ao longo de toda a peça, por meio dos monólogos de Severino, das cenas e das falas das personagens que ele encontra, o auto desvela com elementos risíveis e irônicos um Brasil atrasado, com alta taxa de mortalidade, fome, seca, violência, miséria etc. Antes da entrega dos presentes, fala-se de como o menino recém-nascido é recebido pela natureza do lugar:

$$
\begin{aligned}
& \text { - Todo o céu e a terra } \\
& \text { lhe cantam louvor } \\
& \text { e cada casa se torna } \\
& \text { num mocambo sedutor. } \\
& \text { - Cada casebre se torna } \\
& \text { no mocambo modelar } \\
& \text { que tanto celebram os } \\
& \text { sociólogos do lugar. }
\end{aligned}
$$


J. S. SiqueIRA

Sobre o humor em Morte e Vida Severina (1956), de João Cabral de Melo Neto

\author{
- E a banda de maruins \\ que toda noite se ouvia \\ por causa dele, esta noite, \\ creio que não irradia. \\ - E este rio de água cega, \\ ou baça de comer terra, \\ que jamais espelha o céu, \\ hoje enfeitou-se de estrela. \\ (MELO NETO, 2003, p. 196).
}

O cenário remete-nos ao nascimento de Cristo de modo irônico porque se dá a partir da transformação fantasiosa de elementos locais (mocambo, rio sujo, mosquitos/maruins). Podemos pesar que há no auto uma mensagem de perseverança, resistência, observada, por exemplo, quando os vizinhos, amigos, pessoas que vieram com presentes falam sobre o menino recém-nascido, como no verso "É tão belo como um sim/ numa sala negativa". Esse verso bonito é enigmático e nos convida a pensar sobre seu sentido. Nancy Mendes (1979) comparou a falta de significação desse sim à ineficácia da 'saída' apontada no plano social pela segunda cigana. Pensamos que esse sim é como o próprio auto que, mesmo cheio de negativas, nos convida a pensar criticamente na morte e vida severina, mas não propõe uma solução inequívoca.

A viagem a pé, cortando o estado de Pernambuco de uma vez, não pode corresponder a um fato histórico-concreto e não traz otimismo e heroísmo imbuídos de uma visão revolucionária prenunciando o futuro. A fala do Mestre Carpina, "com o retirante que esteve fora, sem tomar pé de nada”, não pode ser lida como uma resposta conclusiva:

\footnotetext{
é difícil defender,

só com palavras, a vida,

ainda mais quando ela é

esta que vê, severina;

mas se responder não pude

à pergunta que fazia,

ela a vida, a respondeu,

com sua presença viva.

E não há melhor resposta

que o espetáculo da vida:

vê-la desfiar seu fio,

que também se chama vida,

ver a fábrica que ela mesma,

teimosamente se fabrica,
} 


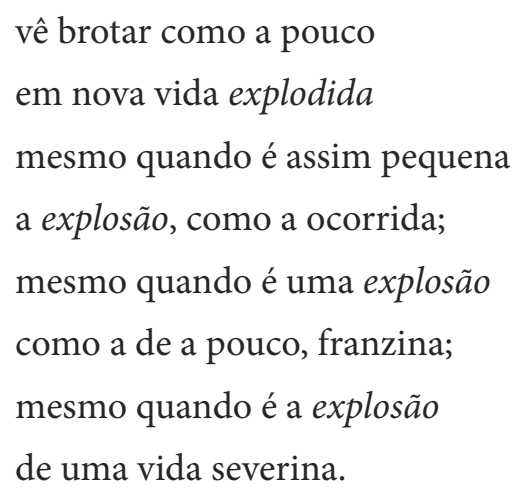

Sua resposta associa a vida que acaba de nascer ao universo do mundo mecânico, fabricado ("fábrica", "fabrica", "explodida", "explosão"), enfatizando, sobretudo com a repetição da palavra "explosão" três vezes no final do texto, seu aspecto de matéria incontida, mas, severina. Se o nascimento da criança, como escreveu Nancy Mendes (1979, p. 48), é "cercado de um ritual que evoca o Natal de Cristo", o novo cristo é severino.

Em 1981, durante a referida entrevista publicada no periódico $O$ Popular, a respeito do auto, João Cabral disse que, propositadamente, deixou o final "ambíguo", e que "apesar de ser confessadamente pessimista, nesse caso não quis tirar qualquer tipo de conclusão, mas acho lícito que as pessoas tirem e que consigam mostrar suas posições" (MELO NETO apud ATHAYDE, 1998, p. 108). Tendo em vista essas palavras, achamos por bem destacar aqui a leitura realizada por Renan Nuernberger (2020, p. 190) no artigo "João Cabral em dois autos: algumas indagações acerca de Morte e vida severina e Auto do frade", por haver identificado relações entre o auto e o ensaio "Da função moderna da poesia", concordando com a pesquisa de Waltencir Alves de Oliveira (2012) sobre a "boa fatura" do auto e, principalmente, por propor, a partir da previsão da segunda cigana para o futuro do recém-nascido, que "o otimismo da peça parece assentado numa visão positiva sobre o processo de modernização que então se esboçava no Brasil". Sobre o final do auto, ressaltou:

\footnotetext{
O que parecia ser um cortejo para seu próprio enterro - antecipado, no meio da peça, pelas orações a outro 'Finado Severino’ (p. 181) - transforma-se de súbito, numa promessa de vida nova pelo nascimento de uma criança. Ainda que o poema mantenha em aberto a decisão final de Severino, o discurso de mestre Carpina, em sua defesa intransigente em favor da vida, mesmo que 'franzina' (p. 222), encerra o auto numa chave positiva que justifica, inclusive, a inversão já presente desde o título - "morte e vida", no lugar da ordem natural de 'vida e morte' (Nuernberger, 2020, p. 190).
} 
J. S. SiQUEIRA

Sobre o humor em Morte e Vida Severina (1956), de João Cabral de Melo Neto

A leitura acima exemplifica as possibilidades de interpretações decorrentes da abertura do texto, mas voltemos ao humor, lembrando-nos de que Benedito Nunes, no capítulo "O 'Inconformado Conformista", clara menção a um verso do "Poema(s) da Cabra", de Quaderna, ao qualificar o humor cabralino, cita uma passagem do prefácio de Breton ao livro Anthologie de l'humour noir, bastante pertinente para nossas considerações finais:

\begin{abstract}
Acre, contundente, desvendando o âmago visível das situações e exibindo o resíduo inumano, a essência cruel da existência, o grotesco e o absurdo das coisas, o humor de João Cabral é, como o humor negro, 'inimigo mortal do sentimentalismo que está sempre à espreita. Mas ao contrário deste que se detém nos limites do grotesco e do absurdo, a atitude humorística de nosso poeta, nutrida por todas as asperezas de que a sinceridade intelectual é capaz, sobe ao extremo da amargura virulenta de Swift, a qual lhe dá a tônica para a impiedade da sátira (NUNES, 1974, p. 166).
\end{abstract}

Na passagem acima, Nunes não se referiu especificamente à obra Morte e vida severina, mas suas palavras são apropriadas para o que observamos a respeito do humor nessa obra. O humor e a ironia presentes em imagens, cenas, falas, situações de Morte e vida severina não provocam um riso fácil, mas acreditamos que percebê-los é necessário para acompanharmos a viagem de Severino sem nos deixarmos invadir pela comoção e para seguirmos acordados.

Muecke (1995, p.61) escreveu que "ver alguma coisa irônica na vida é apresentá-la a alguém como irônica", ainda que possamos "questionar seu sentido ou seu gosto". Foi o que tentamos fazer. A última ironia que desejamos destacar tem relação com o que disse, algumas vezes, João Cabral sobre ter escrito o auto pensando no homem simples, apreciador dos romances de cordel, analfabeto. Na entrevista concedida a Augusto Massi, em 1991, disse:

\footnotetext{
Agora, uma coisa que me decepcionou é que quando eu escrevi 'Morte e vida severina' estava pensando nessa gente, como aquela do engenho, que não sabe ler e ficaria escutado. Quando o livro foi publicado, dei para o Vinícius e ele me veio com o maior entusiasmo. Então eu disse: 'Olha, Vinicius, eu não escrevi este livro para você e sim para o público analfabeto. Mas estou vendo que quem gosta do livro são os intelectuais. Para você escrevi 'Uma faca só lâmina', que é uma coisa difícil'. Foi ingenuidade minha. 'Morte e vida severina' não chega ao povo analfabeto que consome romance de cordel (MELO NETO apud MASSI, 1991, p. 6).
}

Revista Letras,

Curitiba, UFPR, n. 102, pp. 69-93, jul./dez. 2020 ISSN 2236-0999 (versão eletrônica) 
obtido a recepção do público almejado, apreciador da literatura de cordel, mas sim de um público de leitores da poesia erudita, é mais uma ironia observável. O público analfabeto não tem acesso ao que João Cabral escreve, não apenas porque sua poesia é mais comunicativa ou menos. Esse público também não tem acesso ao teatro, ao livro, à leitura e a tantos outros direitos fundamentais. No futuro da criança severina está o trabalho. No auto, o acesso às letras, também é ironizado:

\author{
- Minha pobreza tal é \\ que não tenho presente melhor: \\ trago papel de jornal \\ para lhe servir de cobertor; \\ cobrindo-se assim de letras \\ vai um dia ser doutor
}

(MELO NETO, 2003, p. 197). 
J. S. SiQUEIRA

Sobre o humor em Morte e Vida Severina (1956), de João Cabral de Melo Neto

\section{Referências}

ALBERTI, Verena. O riso e o risível na história do pensamento. 2 ed. Rio de Janeiro: Jorge Zahar, 2002.

ATHAYDE, Félix de. Ideias fixas de João Cabral de Melo Neto. 1. ed. Rio de Janeiro: Nova Fronteira: Fundação Biblioteca Nacional, 1998.

BAUMAN, Zygmunt. Vidas desperdiçadas. Rio de Janeiro: Zahar, 2005.

BERGSON, Henri. O riso: Ensaio sobre a significação da comicidade. Rio de Janeiro: Martins Fontes, 1993.

CARVALHO, Alessandra de. O humor de inspiração ibérica na poesia de João Cabral de Melo Neto. Revista Abriu: Estudos de Textualidade do Brasil, Galícia e Portugal, Barcelona, n. 4, p.121-131, 2015. Disponível em: https:// revistes. ub.edu/index.php/Abriu/article/view/abriu2015.4.8. Acesso em: 20 jul. 2020.

FARIA, Zênia de. Aspectos do grotesco na poesia de João Cabral. Estudos de Literatura Brasileira Contemporânea, Brasília, n.38, p.213-232, jul/ dez. 2011. Disponível em: https://www.scielo.br/scielo.php?script=sci_ arttext\&pid=S2316-40182011000200213. Acesso em: 20 jul. 2020.

MAMEDE, Zilá. Civil geometria: bibliografia crítica, analítica e anotada de João Cabral de Melo Neto. 1. ed. São Paulo: Nobel, 1987.

MELO NETO, João Cabral. Obra completa. Rio de Janeiro: Nova Aguilar, 2003.

- Entrevista. In: INSTITUTO MOREIRA SALES. Cadernos de Literatura Brasileira: João Cabral de Melo Neto, n. 1. São Paulo: Instituto Moreira Sales, 1996. p. 18-31.

João Cabral de Melo Neto [Entrevista a Augusto Massi]. Folha de São Paulo, São Paulo, p. 6, 30 mar. 1991. Disponível em: https:// acervo.folha.com.br/compartilhar.do? numero $=11283 \&$ anchor $=4913104 \&$ pd=19a6686c3a54110624c98a18a6a02aac. Acesso em: 20 jul. 2020.

"A genealogia de Cabral" [Entrevista a Augusto Massi]. Leia, n. 110, dez. 1987.
Revista Letras,

Curitiba, UFPR,

n. 102, pp. 69-93,

jul./dez. 2020

ISSN 2236-0999

(versão eletrônica) 
MENDES, Nancy Maria. Morte e vida severina: um texto parodístico. Cadernos de Linguística e Teoria da Literatura, Belo Horizonte, n. 4, p. 39-50, 1979. Disponível em: http://www.periodicos.letras.ufmg.br/index.php/cltl/ article/view/8573/7426. Acesso em: 6 jul. 2020.

Humor em poemas de João Cabral. Cadernos de Linguística e Teoria da Literatura, Belo Horizonte, n. 12, p. 203-214, 1984. Disponível em: http:// www.periodicos.letras.ufmg.br/index.php/cltl/article/view/9975/8879. Acesso em: 16 jul. 2020.

Sete cemitérios sob perspectiva irônica (Leituras de poemas de João Cabral). O Eixo e a Roda: Revista de Literatura Brasileira, Belo Horizonte, v.2, p.159-165, jun. 1984. Disponível em: http://periodicos.letras.ufmg.br/index. php/o_eixo_ea_roda/article/view/4159/4020. Acesso em: 16 jul. 2020.

MUECKE, D. C. Ironia e o irônico. Trad. Geraldo Gerson de Souza. São Paulo: Perspectiva, 1995.

NUERNBERGER, Renan. João Cabral em dois autos: algumas indagações acerca de Morte e vida severina e Auto do frade. Remate de Males, Campinas, v. 40, n. 1, p. 183-204, jan./jun. 2020.

NUNES, Benedito. João Cabral de Melo Neto. Petrópolis: Vozes, 1974. (Coleção Poetas Modernos do Brasil, v. 1).

OLIVEIRA, Marly. João Cabral de Melo Neto: breve introdução a uma leitura de sua obra. In: MELO NETO, João Cabral. Obra completa. Rio de Janeiro: Nova Aguilar, 2003.

OLIVEIRA, Waltencir Alves de. O gosto dos extremos: tensão e dualidade na poesia de João Cabral de Melo Neto, de Pedra do Sono a Andando Sevilha. São Paulo: Edusp, 2012.

REGO, José Lins. Usina. Rio de Janeiro: José Olympio, 1956.

SALIBA, Elias Thomé. História cultural do humor: balanço provisório e perspectivas de pesquisa. Revista de História, São Paulo, n. 176, p.139, 2017. Disponível em: https://www.revistas.usp.br/revhistoria/article/ view/127332/135577. Acesso em: 20 jul. 2020.

SHIGUEHARA, Alexandre. Ao longo do rio: João Cabral e três poemas do Capibaribe. São Paulo: Ecidade, 2010. 
J. S. SiqueIRA

Sobre o humor em Morte e Vida Severina (1956), de João Cabral de Melo Neto

Recebida em: 31/07/2020

Aceita em: 01/10/2020 